\title{
Rab8 Modulates Metabotropic Glutamate Receptor Subtype 1 Intracellular Trafficking and Signaling in a Protein Kinase C-Dependent Manner
}

\author{
Jessica L. Esseltine, ${ }^{1,2}$ Fabiola M. Ribeiro, ${ }^{3}$ and Stephen S. G. Ferguson ${ }^{1,2}$ \\ ${ }^{1}$ J. Allyn Taylor Centre for Cell Biology, Molecular Brain Research Group, and ${ }^{2}$ Department of Physiology and Pharmacology, University of Western Ontario, \\ London, Ontario N6A 5K8, Canada, and ${ }^{3}$ Departamento de Bioquimica e Imunologia, Instituto de Ciências Biológicas, Universidade Federal de Minas \\ Gerais, Caixa Postal 486, CEP 30161-970, Belo Horizonte, Brazil
}

\begin{abstract}
Metabotropic glutamate receptors (mGluRs) are G protein-coupled receptors (GPCRs) that are activated by glutamate, the primary excitatory neurotransmitter in the CNS. Alterations in glutamate receptor signaling are implicated in neuropathologies such as Alzheimer's disease, ischemia, and Huntington's disease among others. Group $1 \mathrm{mGluRs}$ (mGluR1 and mGluR5) are primarily coupled to G $\alpha_{\mathrm{q} / 11}$ leading to the activation of phospholipase $\mathrm{C}$ and the formation of diacylglycerol and inositol 1,4,5-trisphosphate, which results in the release of intracellular calcium stores and protein kinase $\mathrm{C}(\mathrm{PKC})$ activation. Desensitization, endocytosis, and recycling are major mechanisms of GPCR regulation, and the intracellular trafficking of GPCRs is linked to the Rab family of small G proteins. Rab8 is a small GTPase that is specifically involved in the regulation of secretory/recycling vesicles, modulation of the actin cytoskeleton, and cell polarity. Rab8 has been shown to regulate the synaptic delivery of AMPA receptors during long-term potentiation and during constitutive receptor recycling. We show here that Rab8 interacts with the C-terminal tail of mGluR1a in an agonist-dependent manner and plays a role in regulating of mGluRla signaling and intracellular trafficking in human embryonic kidney 293 cells. Specifically, Rab8 expression attenuates mGluRla-mediated inositol phosphate formation and calcium release from mouse neurons in a PKC-dependent manner, while increasing cell surface mGluR1a expression via decreased receptor endocytosis. These experiments provide us with an understanding of the role Rabs play in coordinated regulation of mGluRla and how this impacts mGluRla signaling.
\end{abstract}

\section{Introduction}

Glutamate is the primary excitatory neurotransmitter in the brain and its actions are mediated through two types of receptors: ionotropic glutamate receptors that are ligand-gated cation channels and metabotropic glutamate receptors (mGluRs) that are G-proteincoupled receptors (GPCRs) (Olney, 1994; Dingledine et al., 1999; Pin et al., 2003). mGluRs play an important role in processes underlying learning and memory, neuronal development, and neurodegeneration (Nakanishi, 1994; Pin et al., 1994; Pin and Duvoisin, 1995; Conn and Pin, 1997; Dale et al., 2002). mGluRs are categorized into three subclasses based on sequence homology and G-protein coupling specificity. Group 1 mGluRs include mGluR1 and mGluR5, which are coupled through $\mathrm{G} \alpha_{\mathrm{q} / 11}$ to the activation of phospholipase $\mathrm{C}$, which in turn catalyzes the formation of inositol 1,4,5-trisphosphate and diacylglycerol, which me-

Received Feb. 9, 2012; revised Sept. 25, 2012; accepted Sept. 27, 2012.

Author contributions: J.L.E., F.M.R., and S.S.G.F. designed research; J.L.E. and F.M.R. performed research; F.M.R. contributed unpublished reagents/analytic tools; J.L.E. analyzed data; J.L.E. and S.S.G.F. wrote the paper.

This work was supported by Canadian Institutes of Health Research (CIHR) Operating Grant MOP-119437 (S.S.G.F.). J.L.E. was the recipient of an Ontario Graduate Studentship. F.M.R. was the recipient of a fellowship from CIHR. S.S.G.F. holds a Tier I Canada Research Chair in Molecular Neurobiology and is a Career Investigator of the Heart and Stroke Foundation of Ontario.

Correspondence should be addressed to Stephen S. G. Ferguson, Molecular Brain Research Group, Robarts Research Institute, 100 Perth Drive, London, Ontario N6A 5K8, Canada. E-mail: ferguson@robarts.ca.

DOI:10.1523/JNEUROSCI.0625-12.2012

Copyright $\odot 2012$ the authors $\quad 0270-6474 / 12 / 3216933-10 \$ 15.00 / 0$ diate the release of intracellular calcium stores and the activation of protein kinase C (PKC) (Conn and Pin, 1997; Dhami and Ferguson, 2006; Niswender and Conn, 2010).

The GPCR desensitization paradigm involves receptor phosphorylation by either second messenger-dependent protein kinases or G-protein-coupled receptor kinases (GRKs) followed by $\beta$-arrestin binding, which functions to uncouple the receptor from the G-protein and targets GPCRs for clathrin-mediated endocytosis (Krupnick and Benovic, 1998; Ferguson, 2001). However, Group I mGluR desensitization and endocytosis is mediated by GRK2 in a phosphorylation-independent manner and does not require $\beta$-arrestin (Ferguson, 2001, 2007; Dhami et al., 2002, 2004, 2005; Dhami and Ferguson, 2006; Ribeiro et al., 2011). Other intracellular regulatory proteins, such as PKC, are implicated in the regulation of glutamate-induced mGluRla internalization, whereas constitutive mGluRla internalization is mediated by RalA and phospholipase D2 (Mundell et al., 2003, 2004; Bhattacharya et al., 2004).

Optineurin, a protein we have previously shown to contribute to the attenuation of mGluRla signaling, has also been shown to be a Rab8 effector protein (Hattula and Peränen, 2000; Anborgh et al., 2005). Rab8 is a member of the Rab GTPase family of small G-proteins that are involved in regulating the trafficking, docking, and fusion of vesicles between intracellular membrane compartments (Zerial and McBride, 2001; Seachrist and Ferguson, 2003; Gáborik and Hunyady, 2004). Rab8 is localized to the Golgi 
apparatus, intracellular membrane vesicles, and membrane ruffles, and is involved in trafficking of basolateral proteins in polarized epithelial cells, neurite outgrowth, delivery and recycling of the ionotropic glutamate AMPA receptors at synapses, and has recently been shown to directly associate with the $\alpha_{2 \mathrm{~B}^{-}}$ and $\beta_{2}$-adrenergic receptors (ARs) (Deretic, 1997; Gerges et al., 2004, 2005; Brown et al., 2007; Ng and Tang, 2008; Dong et al., 2010). Since Rab8 has been shown to interact with optineurin, in the present study we have investigated whether Rab8 contributes to the regulation of mGluRla desensitization and endocytosis. We report that Rab8 interacts with mGluRla in an agonist-regulated manner to antagonize mGluRla endocytosis and coordinates the attenuation of mGluRla-stimulated inositol phosphate (IP) formation and release of $\mathrm{Ca}^{2+}$ from intracellular stores in PKC-regulated manner.

\section{Materials and Methods}

Materials: myo- $\left[{ }^{3} \mathrm{H}\right]$ Inositol was acquired from PerkinElmer Life Sciences. Dowex 1-X8 (formate form) resin 200-400 mesh was purchased from Bio-Rad. Protein A-Sepharose, goat anti-glutathione-S-transferase (GST) antibodies, as well as ECL Western blotting detection reagents were purchased from GE Healthcare. Horseradish peroxidase-conjugated anti-rabbit and anti-goat $\operatorname{IgG}$ secondary antibody was obtained from Bio-Rad. Anti-mGluRla rabbit polyclonal antibody was obtained from Millipore. Rabbit polyclonal phospho-p44/44 MAP kinase (Thr202/Tyr402), p44/44 MAP kinase antibodies, as well as rabbit antiRab8 (D22D8) were obtained from Cell Signaling Technology. Alexa Fluor 488 donkey anti-mouse IgG, Alexa Fluor 568 donkey anti-rabbit IgG, Zenon rabbit Alexa Fluor 555, and fluo-4 AM ester calcium indicators were purchased from Invitrogen. Rabbit anti-FLAG antibody, M2 anti-FLAG agarose, and all other biochemical reagents were purchased from Sigma-Aldrich.

Cell culture. Human embryonic kidney (HEK) 293 cells were maintained in Eagle's minimal essential medium supplemented with $8 \%(\mathrm{v} / \mathrm{v})$ heatinactivated fetal bovine serum (Invitrogen) and $50 \mu \mathrm{g} / \mathrm{ml}$ gentamicin. Cells seeded in $100 \mathrm{~mm}$ dishes were transfected using a modified calcium phosphate method as described previously (Ferguson and Caron, 2004). Following transfection $(18 \mathrm{~h})$, the cells were incubated with fresh medium and allowed to recover for $24 \mathrm{~h}$ for coimmunoprecipitation studies. Otherwise, they were allowed to recover for $6-8 \mathrm{~h}$ and reseeded into 24 -well dishes and then grown an additional $18 \mathrm{~h}$ before experimentation.

Primary hippocampal neuronal culture. Hippocampi from male embryonic day $18 \mathrm{CD}-1$ mice were processed, as described previously (Xie et al., 2000), and maintained in Neurobasal media supplemented with B27, $2 \mathrm{~mm}$ glutamax, $50 \mu \mathrm{g} / \mathrm{ml}$ penicillin, and $50 \mu \mathrm{g} / \mathrm{ml}$ streptomycin. Neurons were transfected at $7-10 \mathrm{~d}$ in vitro (DIV) using a modified calcium phosphate technique and imaged $24 \mathrm{~h}$ later.

Coimmunoprecipitation. HEK 293 cells were transiently transfected with the cDNAs as described in the figure legends. Following transfection, the cells were incubated for $15 \mathrm{~min}$ in HEPES-balanced salt solution (HBSS) at $37^{\circ} \mathrm{C}$ with or without $30 \mu \mathrm{m}$ quisqualate. The cells were then placed on ice, washed two times with ice-cold PBS, and lysed with cold lysis buffer (50 mm Tris, pH 8.0, $150 \mathrm{~mm} \mathrm{NaCl}, 0.1 \%$ Triton X-100) containing protease inhibitors [ $1 \mathrm{~mm} 4$-(2-aminoethyl)benzenesulfonyl fluoride (AEBSF), $10 \mu \mathrm{g} / \mathrm{ml}$ leupeptin, and $5 \mu \mathrm{g} / \mathrm{ml}$ aprotinin]. The lysates were placed on a rocking platform for $15 \mathrm{~min}$ at $4^{\circ} \mathrm{C}$ and centrifuged at $15,000 \times g$ for $15 \mathrm{~min}$ at $4^{\circ} \mathrm{C}$ to pellet insoluble material. Cleared supernatant containing $250 \mu \mathrm{g}$ of protein was incubated with $25 \mu \mathrm{l}$ of FLAG M2-affinity beads for $1 \mathrm{~h}$ rotating at $4^{\circ} \mathrm{C}$ to immunoprecipitate
FLAG-mGluR1a. Endogenous coimmunoprecipitations were performed in freshly isolated hippocampi from adult CD-1 wild-type mice. Briefly, hippocampi were dissected on ice and solubilized by mechanical dissociation in cold lysis buffer (50 mm Tris, pH 8.0, $150 \mathrm{~mm} \mathrm{NaCl}, 1 \%$ Triton $\mathrm{X}-100$ ) containing protease inhibitors ( $1 \mathrm{~mm}$ AEBSF, $10 \mu \mathrm{g} / \mathrm{ml}$ leupeptin, and $5 \mu \mathrm{g} / \mathrm{ml}$ aprotinin). The lysates were rotated for $1 \mathrm{~h}$ at $4^{\circ} \mathrm{C}$ and centrifuged at $15,000 \times g$ for $15 \mathrm{~min}$ at $4^{\circ} \mathrm{C}$ to pellet insoluble material. Supernatant containing $500 \mu \mathrm{g}$ of protein was precleared by incubation with $25 \mu \mathrm{l}$ of protein A-Sepharose beads for $1 \mathrm{~h}$ rotating at $4^{\circ} \mathrm{C}$. Precleared supernatant was incubated overnight with rabbit anti-Rab8 antibody (1:200 dilution) to immunoprecipitate Rab8. Following overnight incubation, $25 \mu \mathrm{l}$ of fresh protein A-Sepharose beads were added to lysate/antibody mixture and rotated for $1 \mathrm{~h}$ at $4^{\circ} \mathrm{C}$. Following incubation, the beads were washed twice with PBS, and proteins were solubilized in a $3 \times$ SDS sample buffer containing 2-mercaptoethanol (BME). Samples were separated by SDS-PAGE, transferred to a nitrocellulose membrane, and immunoblotted to identify coimmunoprecipitated GST-tagged Rab8 protein using a primary goat anti-GST antibody (1:1000 dilution) followed by a horseradish peroxidase-conjugated secondary anti-goat (1:2500 dilution). Receptor and Rab8 protein expression was determined by immunoblotting $10 \mu \mathrm{g}$ of protein from each cell lysate used for immunoprecipitation. Proteins were detected by chemiluminescence.

Biotinylation assay. HEK 293 cells were transiently transfected with the cDNAs as described in the figure legends. For cell surface biotinylation, $48 \mathrm{~h}$ after transfection cells were incubated in warm HBSS for $1 \mathrm{~h}$ and then stimulated with or without $30 \mu \mathrm{M}$ quisqualate. Cells were then placed on ice, washed in ice-cold HBSS, and cell surface proteins labeled with $1.5 \mathrm{mg} / \mathrm{ml}$ biotin for $1 \mathrm{~h}$, and biotin was subsequently quenched with $100 \mathrm{~mm}$ glycine for $30 \mathrm{~min}$. For internalization experiments, cells were labeled with biotin on ice and quenched, and then cells were stimulated with and without $30 \mu \mathrm{m}$ quisqualate for the times indicated in the figure legends to induce mGluRla internalization. Cell surface biotin was stripped from the cells using $150 \mathrm{~mm}$ MesNa. The cells were then placed on ice, washed two times with ice-cold PBS, and lysed with cold lysis 
A
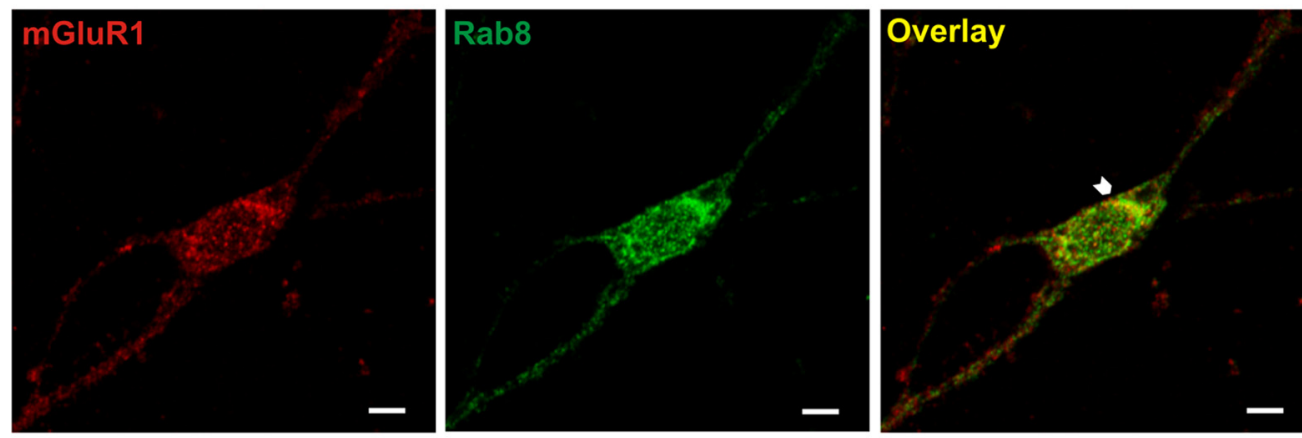

B

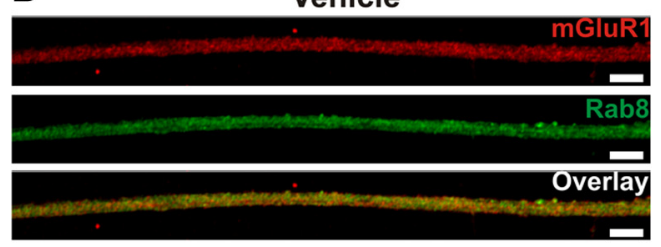

$100 \mu \mathrm{M}$ DHPG

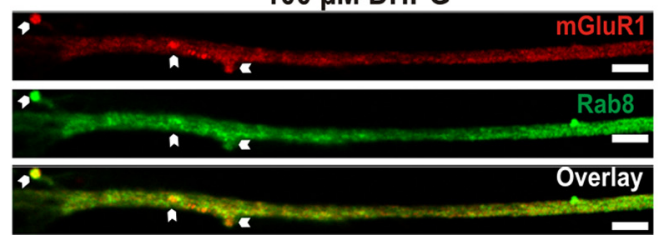

C

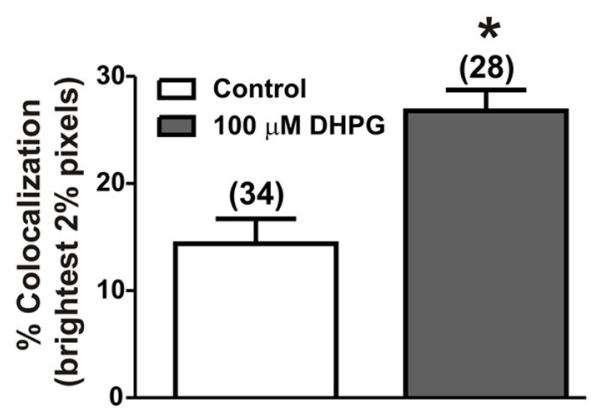

Figure 2. Colocalization of mGluR1 and Rab8 in primary hippocampal neurons. $A$, Representative micrographs showing localization of endogenous mGluR1 and Rab8 protein in neuronal cell body. $\boldsymbol{B}$, Representative micrographs showing localization of mGluR1 and Rab8 in neuronal projections. DIV 14 neurons were treated with and without $100 \mu \mathrm{M}$ DHPG for 30 min, fixed, and labeled for endogenous mGluR1a (red) and Rab8 (green). C, Quantification of Rab8 colocalization with mGluR1 in neuronal projections. Thresholds were set to examine the brightest $2 \%$ of pixels as described by Lorenzen et al. (2010). Data represent mean \pm SD of three independent experiments. Number of dendrites analyzed is provided in brackets in the figure. Scale bars, $5 \mu \mathrm{m} ;{ }^{*} p<0.05$.

buffer (50 mu Tris, pH 8.0, 150 mm NaCl, 0.1\% Triton X-100) containing protease inhibitors ( $1 \mathrm{~mm}$ AEBSF, $10 \mu \mathrm{g} / \mathrm{ml}$ leupeptin, and $5 \mu \mathrm{g} / \mathrm{ml}$ aprotinin). The lysates were placed on a rocking platform for $15 \mathrm{~min}$ at $4^{\circ} \mathrm{C}$ and centrifuged at $15,000 \times g$ for $15 \mathrm{~min}$ at $4^{\circ} \mathrm{C}$ to pellet insoluble material. Cleared supernatant containing $250 \mu \mathrm{g}$ of protein was incubated with $35 \mu \mathrm{l}$ of NeutrAvidin affinity beads for $1 \mathrm{~h}$, rotating at $4^{\circ} \mathrm{C}$ to immunoprecipitate biotin-labeled proteins. Following incubation, the beads were washed twice with PBS, and proteins were solubilized in a $3 \times$ SDS sample buffer containing BME. Samples were separated by SDSPAGE, transferred to a nitrocellulose membrane, and immunoblotted to identify biotinylated mGluRla proteins using a primary rabbit antimGluR1a antibody (1:1000 dilution) followed by a horseradish peroxidase-conjugated secondary anti-rabbit (1:10,000 dilution). Receptor and Rab8 protein expression was determined by immunoblotting 10 $\mu \mathrm{g}$ of protein from each cell lysate used for biotinylation. Proteins were detected by chemiluminescence.

Inositol phosphate formation. HEK 293 cells were transiently transfected with the cDNAs as described in the figure legends. Forty-eight hours after transfection, cells were incubated overnight in inositol- and glutamate-free DMEM with $100 \mu \mathrm{Ci} / \mathrm{ml}$ myo- $\left[{ }^{3} \mathrm{H}\right]$ inositol. For PKC inhibition experiments, cells were washed twice and incubated for $1 \mathrm{~h}$ in warm HBSS, and then preincubated for $10 \mathrm{~min}$ at $37^{\circ} \mathrm{C}$ with either DMSO (control) alone or with $1 \mu \mathrm{M}$ bisindolymaleimide I or $5 \mu \mathrm{M}$ chelerythrine chloride. For all other experiments, cells were incubated for $1 \mathrm{~h}$ in warm HBSS and were then incubated with $10 \mathrm{~mm} \mathrm{LiCl}$ alone for $10 \mathrm{~min}$ followed by $30 \mu \mathrm{M}$ quisqualate treatment for $30 \mathrm{~min}$. Cells were placed on ice, and the reaction was stopped with $500 \mu$ l of perchloric acid and was neutralized with $400 \mu \mathrm{l}$ of $0.72 \mathrm{M} \mathrm{KOH}, 0.6 \mathrm{M} \mathrm{KHCO}_{3}$. Total cellular $\left[{ }^{3} \mathrm{H}\right]$ inositol incorporation was determined in $50 \mu \mathrm{l}$ of cell lysate. Total inositol phosphate was purified by anion exchange chromatography using Dowex 1-X8 (formate form) 200-400 mesh anion exchange resin, and $\left[{ }^{3} \mathrm{H}\right]$ inositol phosphate formation was determined by liquid scintillation using a Beckman LS 6500 scintillation system.

ERK activation. HEK 293 cells were transiently transfected with FLAGmGluR1 and pEGFP (control) or GFP-Rab8. Forty-eight hours after transfection, cells were serum starved overnight in glutamate-free DMEM and stimulated for $0,1,5$, or 15 min with $30 \mu \mathrm{M}$ quisqualate. Cells were lysed and proteins were solubilized in a $3 \times$ SDS sample buffer containing BME. Samples were separated by SDS-PAGE, transferred to a nitrocellulose membrane, and immunoblotted to identify phosphorylated and total extracellular-regulated kinase (ERK1/2) (1:1000 dilution) followed by a horseradish peroxidase-conjugated secondary anti-rabbit (1:10,000 dilution). Receptor and Rab8 protein expression was determined by immunoblotting $10 \mu \mathrm{g}$ of protein from each cell lysate. Proteins were detected by chemiluminescence.

Confocal microscopy. Confocal microscopy was performed using a Zeiss LSM510 META laser-scanning confocal microscope equipped with a Zeiss $63 \times, 1.4$ numerical aperture, oil-immersion lens. HEK 293 cells expressing GFP-Rab8 and FLAG-mGluR1a were serum starved for $1 \mathrm{~h}$ at $37^{\circ} \mathrm{C}$ in HBSS (116 mM NaCl, $20 \mathrm{~mm}$ HEPES, $11 \mathrm{~mm}$ glucose, $5 \mathrm{~mm}$ $\mathrm{NaHCO}_{3}, 4.7 \mathrm{~mm} \mathrm{KCl}, 2.5 \mathrm{~mm} \mathrm{CaCl}, 1.2 \mathrm{~mm} \mathrm{MgSO}_{4}, 1.2 \mathrm{~mm} \mathrm{KH_{2 }} \mathrm{PO}_{4}$, $\mathrm{pH}$ 7.4). HEK 293 cells were prelabeled with Alexa Fluor 568 -conjugated anti-FLAG polyclonal rabbit antibody. Cells were then treated with 30 $\mu \mathrm{M}$ quisqualate, and live cells were imaged over a $30 \mathrm{~min}$ time period at $37^{\circ} \mathrm{C}$. Primary mouse hippocampal neurons were transiently transfected with FLAG-mGluRla, fixed with periodate lysine paraformaldehyde, and permeabilized with $0.1 \%$ Triton X-100. Receptor was labeled with rabbit polyclonal anti-FLAG and endogenous Rab8 labeled with mouse monoclonal anti-Rab8a antibody. Colocalization studies were performed using dual excitation $(488,543 \mathrm{~nm})$ and emission (bandpass, $505-530 \mathrm{~nm}$, and long pass, $560 \mathrm{~nm}$, for Alexa Fluor 488 and 568, respectively) filter sets. Colocalization analysis was performed using Imaris 7.0 
colocalization module (Bitplane) to determine the colocalization of the brightest $2 \%$ of pixels in each channel, as described previously (Lorenzen et al., 2010). Quantification of receptor internalization in confocal images was performed using Image integrated density of fluorescence before and after agonist stimulation. Data were presented as ratio of membrane fluorescence over intracellular fluorescence.

Calcium imaging. DIV 7-10 hippocampal neurons were transiently transfected with either empty pEGFP (control) or GFP-Rab8 and imaged $24 \mathrm{~h}$ later. Transfected cells were identified via confocal microscopy at $488 \mathrm{~nm}$ excitation and bandpass 505-530 emission after which cells were loaded with $10 \mu \mathrm{M}$ fluo- $4 \mathrm{AM}$ for $30 \mathrm{~min}$ at room temperature and imaged using the same parameters. Cells were stimulated with $100 \mu \mathrm{M}$ DHPG, $100 \mu \mathrm{M}$ carbachol, and $1 \mu \mathrm{M}$ ionomycin.

Statistical analysis. Densitometric data were normalized first for protein expression and the maximum value was set to 100 , with all other values displayed as percentage thereof. One-way ANOVA test was performed to determine significance, followed by a post hoc Tukey multiple-comparison test or Bonferroni's multiple-comparisons test to determine which means were significantly different $(p<0.05)$ from one another.

\section{Results}

Agonist-stimulated Rab8 interaction with the mGluR1a C-tail

Previously, we demonstrated that the Rab8 effector optineurin was an mGluRla interacting protein by yeast two-hybrid and that it played a role in antagonizing mGluR1a G-protein signaling (Anborgh et al., 2005). Therefore, in the present study, we investigated whether Rab8 might also interact with mGluRla. To do this, HEK 293 cells were transiently transfected with FLAG-tagged mGluRla or FLAG-mGluR1b and GST-tagged Rab8, and the coimmunoprecipitation of GSTRab8 with either FLAG-mGluR1a or FLAG-mGluR1b was assessed. We found that GST-Rab8 was coimmunoprecipitated with FLAG-mGluR1a in the absence of agonist, but that this association was increased by $92 \pm 23 \%$ in response to 30 $\mu \mathrm{M}$ quisqualate treatment (Fig. $1 A, B$ ). In contrast, GST-Rab8 coimmunoprecipitation with Flag-mGluR1b (which lacks an extended intracellular C-tail) was reduced to $72 \pm 7 \%$ of control FLAG-mGluR1a immunoprecipitation (Fig. $1 A, B)$. Agonist treatment did not increase GST-Rab8 coimmunoprecipitation with FLAG-mGluR1b (Fig. 1A,B). Therefore, agonist-dependent increases in Rab8 association with mGluRla required interactions with the extended mGluRla C-tail. We also sought to determine whether endogenous Rab8 associates with endogenous mGluRla in hippocampal tissue. We found that mGluRla could be coimmunoprecipitated with Rab8-specific antibody from freshly isolated adult mouse hippocampal lysate (Fig. 1C).

A

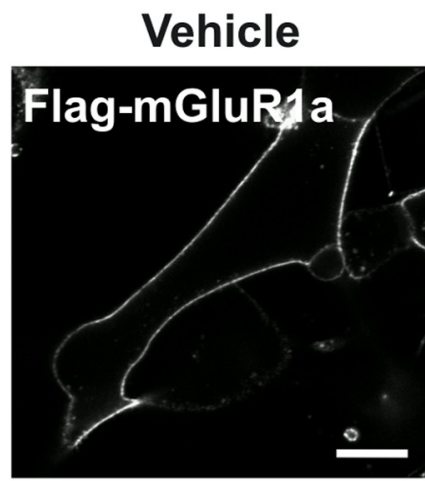

$30 \mu M$ Quis, 15 min
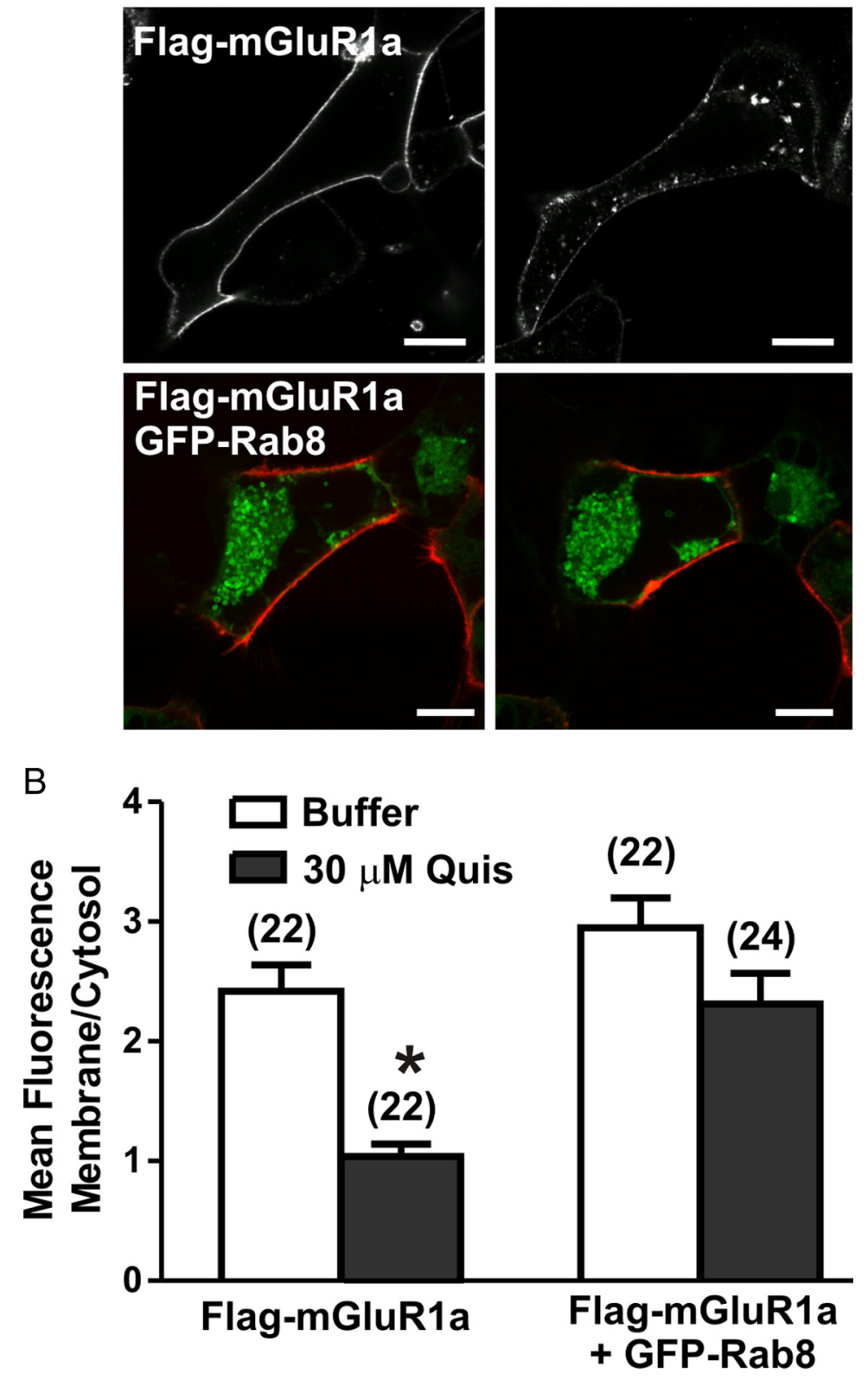

Figure 3. Live-cell imaging of mGluR1a endocytosis in the absence and presence of Rab8. $\boldsymbol{A}$, Representative confocal micrograph showing internalization of FLAG-mGluR1a in the presence and absence GFP-Rab8. Live HEK 293 cells expressing $1 \mu \mathrm{g}$ of plasmid cDNA encoding FLAG-mGluR1a either with (bottom panels) or without (top panels) $2 \mu \mathrm{g}$ of plasmid cDNA encoding GFP-Rab8 were labeled with Zenon Alexa Fluor 555 on ice, warmed to $37^{\circ} \mathrm{C}$, and stimulated with $30 \mu \mathrm{m}$ Quis for $15 \mathrm{~min}$. B, Quantification of internalization of FLAGmGluR1a. Data are presented as ratio of membrane fluorescence over intracellular fluorescence and represent mean \pm SD of five independent experiments. The number of cells analyzed is provided in brackets in the figure. Scale bars, $5 \mu \mathrm{m} ;{ }^{*} p<0.05$.

To determine whether Rab8 colocalizes with FLAG-mGluRla, primary hippocampal neurons (DIV 14) were fixed and labeled for FLAG-mGluRla and endogenous Rab8 protein distribution and imaged using confocal microscopy. Interestingly, while FLAGmGluRla and Rab8 share partial overlapping populations in the neuronal cell body (Fig. $2 A$ ), they show limited colocalization in neuronal projections in the absence of agonist (Fig. $2 B$ ). However, following the treatment of hippocampal neurons with $100 \mu \mathrm{M}(S)$ 3,5-dihydroxylphenylglycine (DHPG), both FLAG-mGluR1a and Rab8 immunofluorescence exhibited colocalization in the spines of these projections (Fig. 2 B). To quantify the amount of colocalization in neuronal projections before and after treatment with DHPG, we 
A
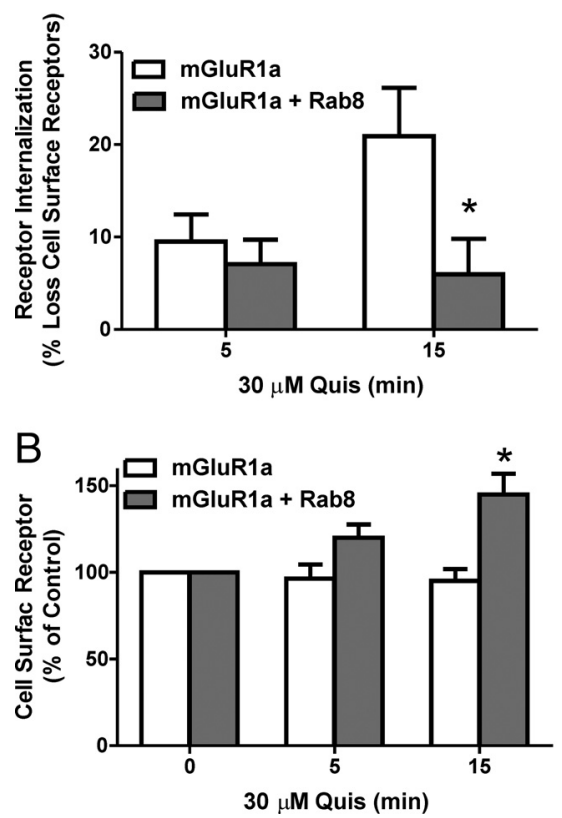

Figure 4. Effect of Rab8 on mGluR1a endocytosis and cell surface expression. $A$, Representative immunoblot and densitometric analysis of internalized biotinylation of FLAG-mGluR1a. HEK 293 cells transiently expressing $1 \mu \mathrm{g}$ of FLAG-mGluR1a and $2 \mu \mathrm{g}$ of either pEBG (control) or GST-Rab8 were placed on ice, and cell surface proteins were biotinylated. Cells were then stimulated with $30 \mu \mathrm{m}$ Quis for 0,5 , or $15 \mathrm{~min}$ to induce internalization, and cell surface biotin stripped away. Biotin-labeled proteins were collected with NeutrAvidin-conjugated beads, separated by SDS-PAGE, transferred to nitrocellulose, and immunoblotted for mGluR1a. Data were normalized for protein expression. Data represent the mean \pm SD of six independent experiments. ${ }^{*} p<0.05$ compared with corresponding control. $\boldsymbol{B}$, Representative immunoblot and densitometric analysis of cell surface biotinylation of FLAG-mGluR1a. HEK 293 cells transiently expressing $1 \mu \mathrm{g}$ of FLAG-mGluR1a and $2 \mu \mathrm{g}$ of either $\mathrm{pEBG}$ (control) or GST-Rab8 were stimulated with $30 \mu \mathrm{m}$ Quis for 0, 5, or $15 \mathrm{~min}$, placed on ice, and cell surface proteins were biotinylated. Biotin-labeled proteins were collected with NeutrAvidin-conjugated beads, separated by SDS-PAGE, transferred to nitrocellulose, and immunoblotted for mGluR1a. Data represent the mean $\pm S D$ for changes in cell surface mGluR1 expression. Data were normalized for protein expression and are representative of six independent experiments. ${ }^{*} p<0.05$ compared with corresponding control.

set thresholds to examine the brightest $2 \%$ of pixels as described by Lorenzen et al. (2010). Rab8 and mGluR1 pixels from control neurons demonstrated $14 \pm 2 \%$ colocalization, while agonist activation increased this colocalization to $27 \pm 2 \%$ (Fig. 2C). Thus, agonist treatment appeared to increase FLAG-mGluRla and endogenous Rab8 association in primary cells.

\section{Rab8 antagonizes mGluR1a endocytosis to increase cell surface receptor expression}

Rab8 has been shown to differentially regulate the trafficking of the $\alpha_{2 \mathrm{~B}} \mathrm{AR}$ and $\beta_{2} \mathrm{AR}$ and contributes to the regulation of the synaptic delivery and recycling of the ionotropic glutamate AMPA receptor (Deretic, 1997; Gerges et al., 2004; Brown et al., 2007; Ng and Tang, 2008; Dong et al., 2010). Therefore, we investigated whether Rab8 overexpression would affect FLAGmGluRla intracellular trafficking in HEK 293 cells. Initial experiments were performed by confocal microscopy to determine whether Rab8 overexpression resulted in an alteration of cell surface FLAG-mGluR1a in live HEK 293 cells labeled with Zenon 555 Alexa Fluor-labeled primary mouse FLAG monoclonal antibody. Control cells expressing FLAG-mGluR1a alone showed steady receptor internalization upon treatment with 30 $\mu \mathrm{M}$ quisqualate (Fig. $3 \mathrm{~A}$, top panels). Agonist stimulation resulted in $57 \pm 8 \%$ reduction in the ratio of cell surface to intracellular Flag-mGluR1a immunofluorescence (Fig. 3B). However, in cells overexpressing GFP-Rab8, cell surface FLAG-mGluR1a, the ratio was reduced by only $22 \pm 10 \%$ following quisqualate treatment (Fig. 3A, bottom panels; $B$ ). To further quantify the extent of FLAGmGluR1a internalization in the absence and presence of Rab8, we tested FLAGmGluRla endocytosis using a cell surface biotyinylation assay following 5 and 15 min exposures to $30 \mu \mathrm{M}$ quisqualate. We found that following a $15 \mathrm{~min}$ exposure of FLAG-mGluR1a to agonist that FLAGmGluR1a internalization was significantly reduced in HEK 293 cells overexpressing Rab8, when compared with control cells (Fig. 4A). When we assessed the overall cell surface expression of FLAG-mGluRla, we found that the fraction of FLAGmGluRla at the cell surface following 15 min agonist treatment was significantly increased compared with control cells (Fig. 4B). Therefore, Rab8 appeared to prevent mGluRla endocytosis and increase cell surface mGluRla expression.

\section{Rab8 antagonizes mGluR1a inositol phosphate and calcium signaling} The Rab8 effector molecule, optineurin, is known to contribute to phosphorylationindependent G-protein uncoupling and desensitization of mGluRla (Anborgh et al., 2005). Therefore, we assessed whether Rab8 overexpression would also result in altered FLAG-mGluR1a- and FLAGmGluR1b-stimulated IP formation in HEK 293 cells. We found that the overexpression of Rab8 resulted in a significant reduction in the maximal response for quisqualatestimulated IP formation in FLAG-mGluR1aexpressing cells reducing the maximum response to $70 \pm 7 \%$ when compared with control FLAG-mGluRla-expressing cells (Fig. 5A). However, Rab8 overexpression had no effect on the maximal response for quisqualate-stimulated IP formation in FLAG-mGluR1b-expressing cells (Fig. 5B). Thus, consistent with what was observed for agonist-stimulated association of Rab8 with mGluR1a versus mGluR1b, Rab8 overexpression selectively attenuated mGluR1a and not mGluR1b G-protein signaling.

To determine whether Rab8 GDP for GTP exchange was required for the attenuation of FLAG-mGluRla-stimulated IP formation, we assessed whether FLAG-mGluRla-stimulated IP formation would be inhibited in the presence of either dominant-negative (Rab8-T22N) or constitutively active (Rab8-Q67L) proteins. We found that the overexpression of wild-type Rab8, Rab8-T22N, and Rab8-Q67L resulted in a reduction of FLAG-mGluR1a stimulated IP formation to a similar extent (Fig. 6A). To determine whether Rab8 associated with the receptor in a nucleotide-specific manner, we also examined the agoniststimulated coimmunoprecipitation of wild-type Rab8, Rab8T22N, and Rab8-Q67L with FLAG-mGluR1a. Although FLAG-mGluR1a interactions with both wild-type Rab8 and constitutively active Rab8-Q67L were increased upon agonist stimulation, agonist did not regulate the association of dominant-negative Rab8-T22N with the receptor (Fig. 6B). Thus, although Rab8 associated with mGluR1a in a GTPdependent manner, the Rab8-dependent attenuation of 
mGluR1a G-protein signaling was independent of the nucleotide-binding state of the GTPase.

Because we found that Rab8 significantly attenuated FLAG-mGluR1a-mediated IP formation in HEK 293 cells, we investigated whether Rab8 overexpression might also attenuate DHPG-stimulated $\mathrm{Ca}^{2+}$ release mediated by endogenous mGluR1 expressed in primary hippocampal neurons. To assess this, primary mouse hippocampal neurons (DIV7-10) were transiently transfected with either pEGFP (control) or GFP-Rab8. Neurons were imaged to identify cells that were transfected with GFP protein, and GFP protein-positive cells were then subsequently loaded with the calcium indicator fluo-4 AM and the same cell imaged for DHPG mediated calcium release as evidenced by an increase in cellular fluorescence. The treatment of hippocampal neurons with $100 \mu \mathrm{M}$ DHPG resulted in an increase in fluo-4 fluorescence in both untransfected and pEGFP-transfected neurons as expected (Fig. 7A). However, in GFP-Rab8-positive neurons, DHPG-stimulated increases in intracellular $\mathrm{Ca}^{2+}$ concentration, as measured by increased fluo- 4 fluorescence, was attenuated (Fig. 7A). All of the cells exhibited similar responses to challenge with ionomycin indicating that GFP-Rab8 overexpression was not causing a generalized defect in $\mathrm{Ca}^{2+}$ regulation (Fig. $7 A$ ). To determine whether the effect of Rab8 on $\mathrm{Ca}^{2+}$ signaling was specific to mGluRs, we also stimulated neurons with the cholinergic agonist carbachol (Fig. $7 B$ ). Contrary to what was observed after DHPG stimulation, treatment with $100 \mu \mathrm{M}$ carbachol produced equivalent increases in fluo- 4 fluorescence in control neurons, as well as those transfected with either pEGFP (control) or GFP-Rab8 (Fig. 7B). Therefore, the Rab8-mediated decrease in $\mathrm{Ca}^{2+}$ release appears to be specific for mGluRmediated $\mathrm{Ca}^{2+}$ signaling. To investigate whether Rab8 overexpression also affected other aspects of mGluRla signaling, we examined FLAG-mGluR1a-stimulated ERK1/2 phosphorylation in HEK 293 cells (Fig. 8). We found that agoniststimulated FLAG-mGluRla-mediated ERK1/2 phosphorylation was not affected by the overexpression of Rab8 (Fig. 8). Therefore, Rab8 appeared to selectively regulate FLAG-mGluR1a-stimulated IP formation in HEK 293 and $\mathrm{Ca}^{2+}$ release in response to the activation of endogenous mGluR1/5 in primary mouse hippocampal neurons.

\section{Rab8 decrease of mGluR1a-mediated IP} signaling is PKC dependent

Second messenger-dependent kinases, such as PKC, can contribute to the desensitization of agonist-activated Group 1 mGluRs (Schoepp and Johnson, 1988; Herrero et al., 1994; Desai et al., 1996; Francesconi and Duvoisin, 2000; Ferguson, 2001). Because we found that Rab8 expression causes a significant decrease in FLAG-mGluR1a-mediated IP formation, we sought to determine whether PKCmediated desensitization of mGluRla signaling might be influenced by Rab8 expression. To test this, HEK 293 cells were pretreated with one of two PKC inhibitors, bisindolylmaleimide-1 (Bis-1) or chelerythrine chloride. We found that the pretreatment of HEK 293 cells with either $1 \mu \mathrm{M}$ Bis-1 or $5 \mu \mathrm{M}$ chelerythrine chloride for 10 min prevented the
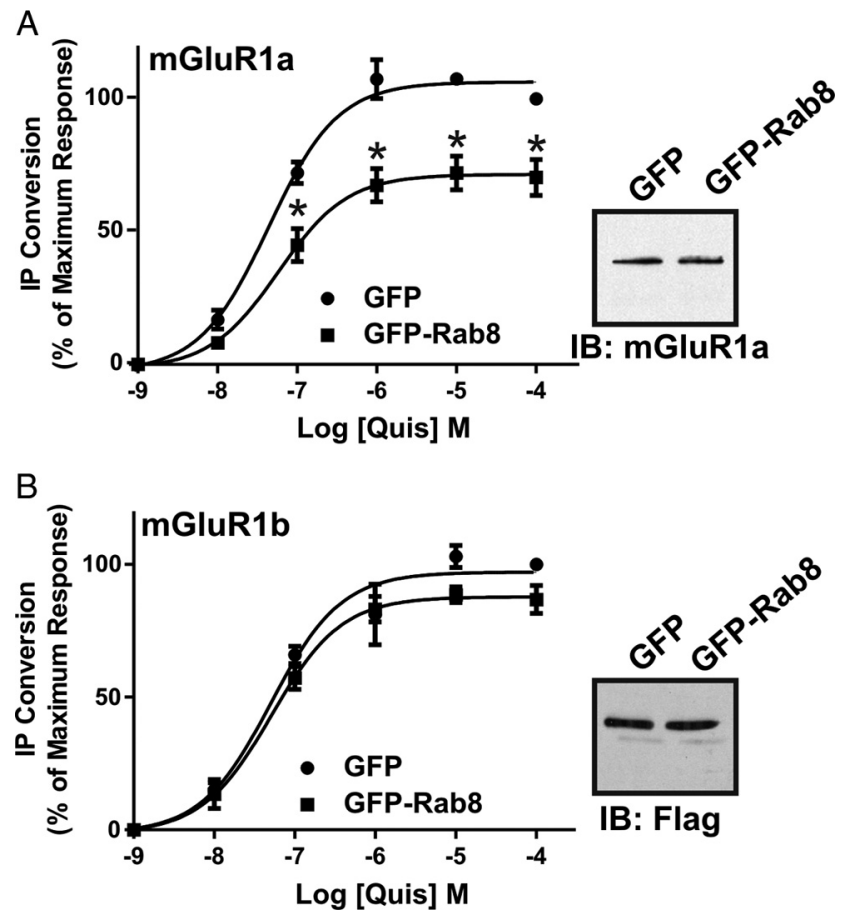

Figure 5. Effect of Rab8 on mGluR1a- and mGluR1b-mediated IP formation. Inositol phosphate formation in HEK 293 cells transfected with $1 \mu \mathrm{g}$ of plasmid CDNA encoding FLAGmGluR1a $(\boldsymbol{A})$ or FLAG-mGluR1b $(\boldsymbol{B})$ with $2 \mu \mathrm{g}$ of empty pEGFP vector or GFP-Rab8. Transfected cells were treated for $10 \mathrm{~min}$ with $10 \mathrm{~mm}$ LiCl and stimulated with $30 \mu \mathrm{m}$ Quis for $30 \mathrm{~min}$ in the presence of LiCl. Data were normalized for protein expression and basal IP formation. The bottom panels show relative mGluR1a and mGluR1b protein expression in GFP and GFP-Rab8 transfected cells. Data represent the mean \pm SD of three to five independent experiments. ${ }^{*} p<0.05$ compared with corresponding control.

\section{A}
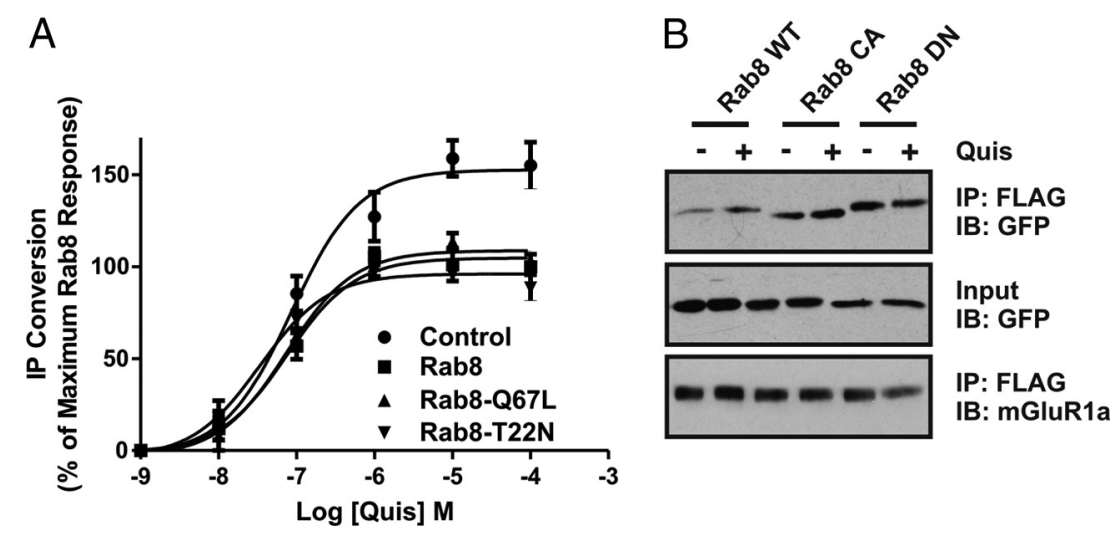

Figure 6. Effect of Rab8 nucleotide binding mutants on mGluR1a-mediated inositol phosphate formation. $A$, IP formation in HEK 293 cells transfected with $1 \mu \mathrm{g}$ of plasmid CDNA encoding FLAG-mGluR1a with $2 \mu \mathrm{g}$ of plasmid CDNA encoding GFP-tagged wild-type (WT) Rab8, constitutively active (CA) Rab8-067L, and dominant-negative (DN) Rab8-T22N mutants. Transfected cells were treated for $10 \mathrm{~min}$ with $10 \mathrm{~mm} \mathrm{LiCl}$ and stimulated with $30 \mu \mathrm{m}$ quisqualate (Quis) for $30 \mathrm{~min}$ in the presence of LiCl. Data were normalized for protein expression and basal IP formation. $\boldsymbol{B}$, Representative immunoblot showing the coimmunoprecipitation of GST-tagged Rab8WT, Rab8CA and Rab8DN with the FLAG-mGluR1a in the absence $(-)$ and presence $(+)$ of $30 \mu \mathrm{m}$ Quis treatment for $15 \mathrm{~min}$. HEK 293 cells were transiently transfected with $1 \mu \mathrm{g}$ of plasmid cDNA encoding FLAG-mGluR1a along with $2 \mu \mathrm{g}$ of plasmid cDNA encoding GST-tagged Rab8WT, Rab8CA, or Rab8DN. Forty-eight hours after transfection, cells were stimulated, and lysates were collected, separated by SDS-PAGE, transferred to nitrocellulose, and immunoblotted for mGluR1a and GST-Rab8. Data represent the mean \pm SD of three to five independent experiments.

Rab8-mediated uncoupling of mGluR1a-stimulated IP formation to DMSO control levels (Fig. 9). This observation suggested a role for PKC-mediated phosphorylation in the observed Rab8dependent attenuation of FLAG-mGluR1a IP signaling. 
A

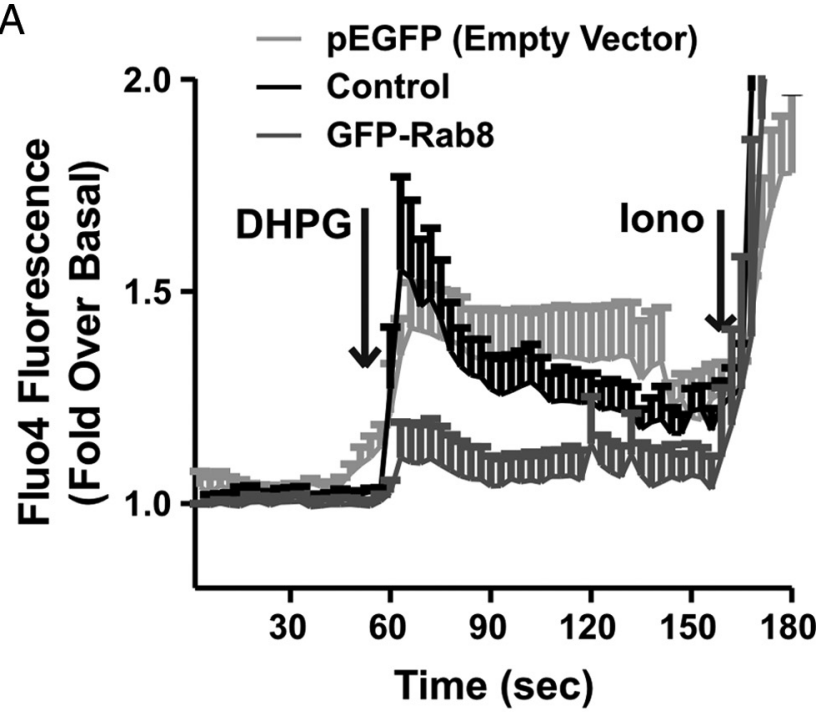

B

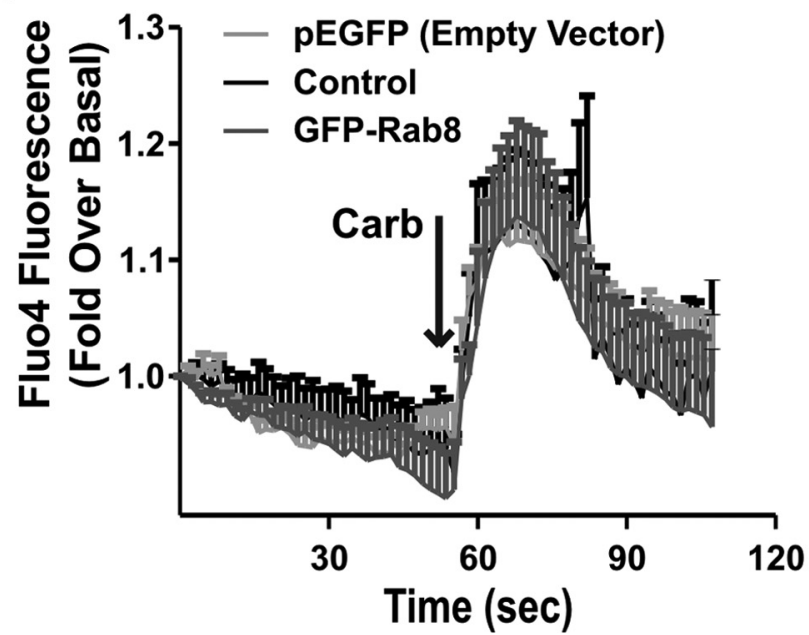

Figure 7. Effect of Rab8 on DHPG-stimulated $\mathrm{Ca}^{2+}$ release in hippocampal neurons. Fluorescent intensity analysis of $\mathrm{Ca}^{2+}$ release as represented by the fluorescent calcium indicator fluo-4 AM. DIV7-10 primary mouse hippocampal neurons were transiently transfected with 10 $\mu \mathrm{g}$ of plasmid cDNA encoding either pEGFP (control) or GFP-Rab8. Twenty-four hours after transfection, neurons were imaged to identify transfected cells, after which they were loaded with $5 \mu \mathrm{m}$ of the calcium indicator fluo-4 AM for $30 \mathrm{~min}$ at room temperature, and the same field of view was imaged for calcium release with the addition of $100 \mu \mathrm{m}$ DHPG followed by 10 $\mu \mathrm{m}$ ionomycin $(\boldsymbol{A})$ or $100 \mu \mathrm{m}$ carbachol $(\boldsymbol{B})$. Data represent the mean \pm SD of three independent experiments.

\section{Discussion}

To date, only a few Rabs including Rab3, Rab8, and Rab23 have been shown to be enriched in the brain and play a role in neurons (Geppert et al., 1997; Evans et al., 2003; Ng and Tang, 2008). Rab8 is essential in several areas of polarized neuronal transport as well as in plasma membrane trafficking in epithelial cells, and Rab8 siRNA knockdown prevents maturation of hippocampal neurons in culture (Huber et al., 1995; van Ijzendoorn et al., 2003; Ng and Tang, 2008). Studies now link Rab8 to a variety of different human diseases, including polycystic kidney disease, microvillus inclusion disease, and Bardet-Biedl syndrome, emphasizing the physiological importance of protein trafficking in human disease (Nachury et al., 2007; Ng and Tang, 2008). Here, we show that Rab8 associates with mGluRla, but not its alternatively spliced variant, mGluR1b, which lacks an extended C-terminal tail, sug-
mGluR1a
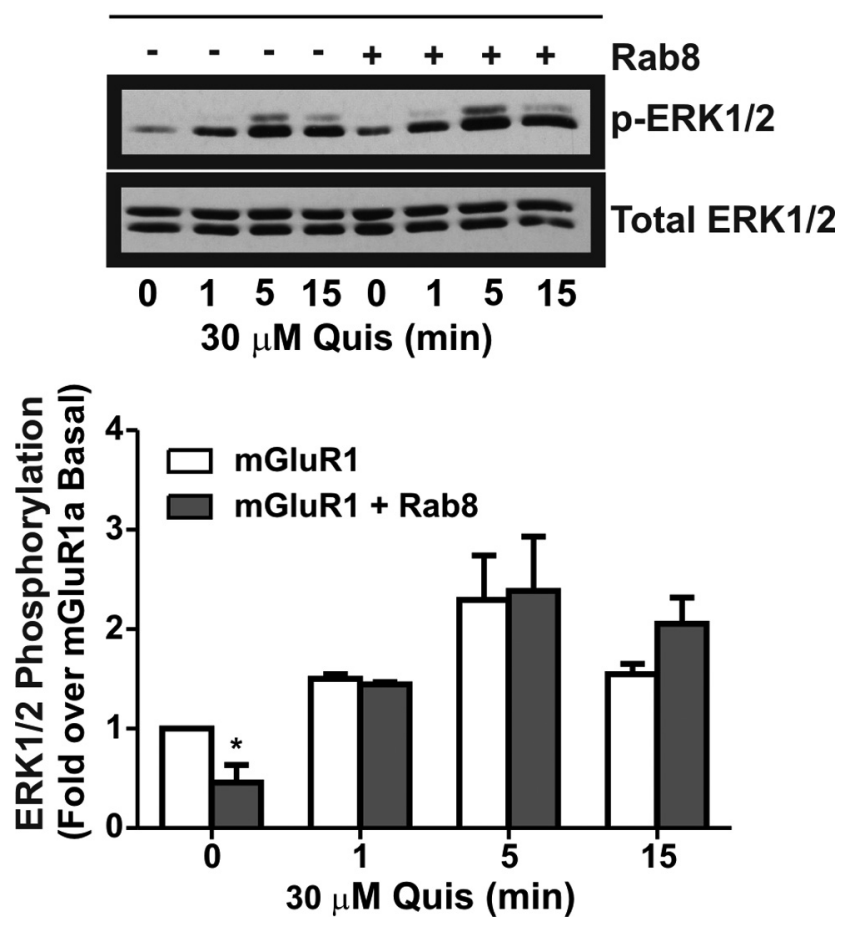

Figure 8. Effect of Rab8 on mGluR1a-stimulated ERK1/2 phosphorylation. Shown is a representative immunoblot and densitometric analysis of p42/44 (ERK1/2) phosphorylation. HEK 293 cells were transiently transfected with $1 \mu \mathrm{g}$ of plasmid CDNA encoding FLAG-mGluR1a along with $2 \mu \mathrm{g}$ of plasmid cDNA encoding either pEGFP (control) or GFP-Rab8. Cells were stimulated for $0,1,5$, or 15 min with $30 \mu \mathrm{m}$ Quis, lysates were collected, separated by SDS-PAGE, and transferred to nitrocellulose, and phosphorylated ERK1/2 was detected by immunoblot. Data were normalized for total ERK expression. Data represent the mean $\pm S D$ of five independent experiments.

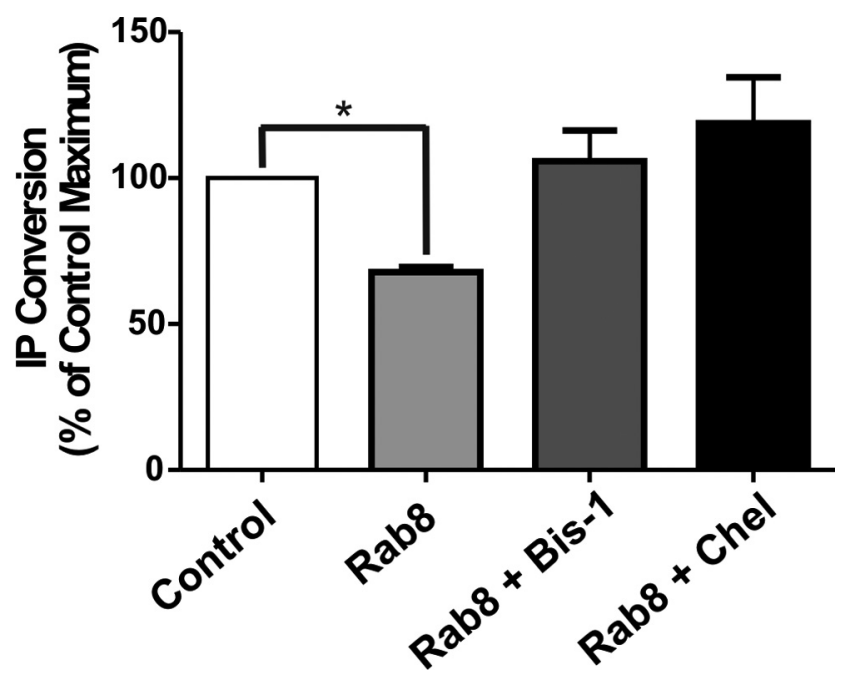

Figure 9. PKC inhibition prevents Rab8-dependent attenuation of mGluR1a-mediated IP formation. HEK 293 cells were transfected with $1 \mu \mathrm{g}$ of plasmid CDNA encoding FLAG-mGluR1a along with $2 \mu \mathrm{g}$ of empty pEGFP vector (control) or GFP-Rab8. Cells were preincubated for $10 \mathrm{~min}$ with either DMSO alone or with either $1 \mu \mathrm{m}$ bisindolymaleimide I or $5 \mu \mathrm{m}$ chelerythrine chloride followed by 10 $\mathrm{mm}$ LiCl for $10 \mathrm{~min}$ and then $10 \mu \mathrm{m}$ quisqualate for $30 \mathrm{~min}$. Data were normalized for protein expression and basal IP formation. Data represent the mean \pm SD of five independent experiments. ${ }^{*} p<$ 0.05 compared with control.

gesting that Rab8 binds to the C-terminal tail of mGluRla in an agonist-regulated manner. Other Rabs, including Rab4, Rab5, Rab7, and Rab11, have previously been reported to associate with the C-terminal tail of the angiotensin II type 1 receptor and other 


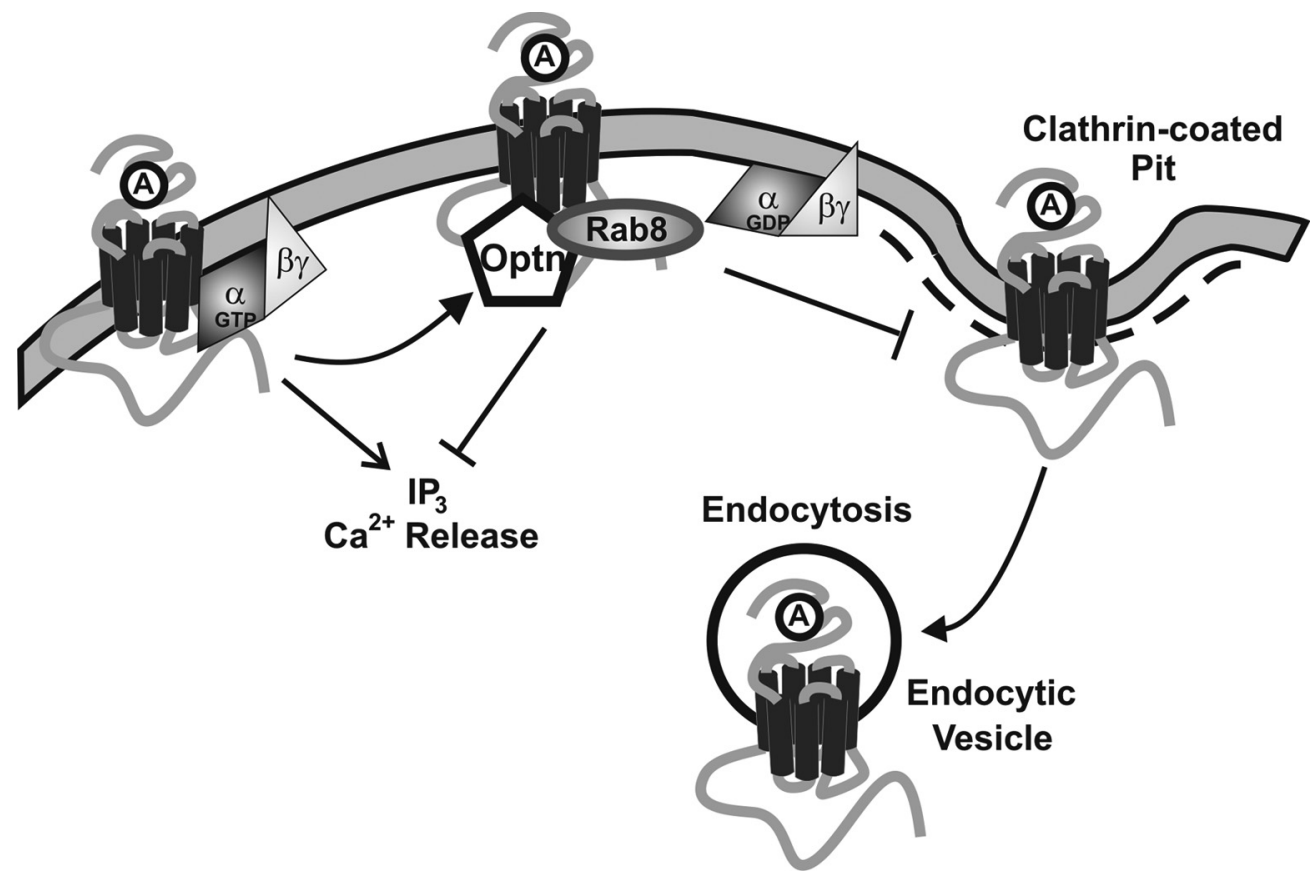

Figure 10. Model for optineurin and Rab8-mediated attenuation of mGluR1a signaling and endocytosis. Agonist activation of mGluR1a results in the recruitment of Rab8, which interacts with the mGluR1a, but not mGluR1b C-terminal tail. Rab8 functions in concert with optineurin to attenuate mGluR1a G-protein coupling, resulting in diminished IP formation and impaired release of $\mathrm{Ca}^{2+}$ from intracellular stores. Rab8, but not optineurin, interactions with mGluR1a impair mGluR1a endocytosis and result in an increase in cell surface mGluR1a expression. Optn, 0ptineurin.

GPCRs (Anborgh et al., 2000; Seachrist et al., 2002; Dale et al., 2004; Hamelin et al., 2005; Parent et al., 2009; Reid et al., 2010; Esseltine et al., 2011). Additionally, Rab8 has recently been shown to associate with different regions of the $\alpha_{2 \mathrm{~B}} \mathrm{AR}$ and $\beta_{2} \mathrm{AR}$ C-terminal tails and differentially modulates their trafficking to the cell surface from the trans-Golgi network (TGN) (Dong et al., 2010). We find that the association of Rab8 contributes to attenuated mGluRla endocytosis, increased cell surface expression, and functions to uncouple mGluR1a from G-protein signaling by a mechanism that requires PKC activity.

Agonist-activated mGluR1a preferentially binds Rab8 wildtype and GTP-bound constitutively active mutant Rab8Q67L, but not GDP-bound dominant-negative mutant Rab8-T22N. This differs from the $\alpha_{2 \mathrm{~B}} \mathrm{AR}$ and $\beta_{2} \mathrm{AR}$, which were recently shown to bind preferentially bind the GDP-bound dominantnegative mutant Rab8-T22N (Dong et al., 2010). However, although this study did not investigate whether agonist activation regulated Rab8 interactions with the $\alpha_{2 \mathrm{~B}} \mathrm{AR}$ and $\beta_{2} \mathrm{AR}$, Rab8 knockdown resulted in attenuated cell surface expression of the $\alpha_{2 \mathrm{~B}} \mathrm{AR}$. Rab8 also has documented roles in the intracellular trafficking of other receptors such as the transferrin receptor, and has been shown to drive synaptic delivery of ionotropic glutamate AMPA receptors and their insertion into synaptic membranes (Brown et al., 2007; Henry and Sheff, 2008). However, to date, most studies have focused on the role of Rab8 in regulating receptor delivery to the plasma membrane from areas such as the TGN or recycling endosomes (Deretic, 1997; Gerges et al., 2004, 2005; Brown et al., 2007; Dong et al., 2010). We present data here implicating Rab8 in the inhibition of mGluRla internalization. Similar to our findings, the Rab8 effector molecule optineurin is also implicated in attenuating the internalization of transferrin receptors (Nagabhushana et al., 2010; Park et al., 2010). Rab5 has a well documented role in facilitating endocytosis of a number of receptors including the angiotensin II type 1 receptor and $\beta_{2} \mathrm{AR}$ (Seachrist et al., 2000, 2002; Dale et al., 2004). However, to our knowledge, Rab8 represents the first example of a wild-type Rab protein that contributes to the attenuation of receptor endocytosis.

Interestingly, we find that Rab8 overexpression leads to an increase in cell surface mGluRla expression. This increase in cell surface expression might be explained by one of two mechanisms: (1) Rab8 overexpression increases cell surface expression by either reducing constitutive mGluRla internalization or agonist-stimulated internalization of mGluRla as the consequence of the release of endogenous glutamate into the media by HEK 293 cells. (2) Rab8 overexpression facilitates the movement of receptors from the TGN to the plasma membrane. This would be similar to what was observed for the $\alpha_{2 \mathrm{~B}} \mathrm{AR}$, where Rab8 knockdown led to impaired TGN to plasma membrane transport of the receptor (Dong et al., 2010). In hippocampal neurons, endogenous Rab8 along with the mGluR1a redistribute to spine regions after agonist stimulation, suggesting that Rab8 may regulate the localization of mGluRla to synapse. This might be similar to reported role of Rab8 in the neuronal trafficking and insertion of the ionotropic AMPA-type glutamate receptor at synapses (Gerges et al., 2004, 2005).

Our laboratory has previously reported that the Rab8 effector molecule optineurin associates mGluRla, resulting in attenuated mGluRla-stimulated IP formation (Anborgh et al., 2005). In the present study, we find that Rab8 also contributes to the regulation of mGluRla G-protein signaling in concert with optineurin, whereas Rab8, but not optineurin, plays a role in attenuating mGluRla endocytosis (Fig. 10). We find that Rab8 overexpression specifically contributes to the uncoupling of mGluRla-, but not mGluR1b-stimulated IP formation. This inability of Rab8 to regulate $\mathrm{mGluR} 1 \mathrm{~b}$ signaling is correlated with the observations that mGluR1b lacks an extended C-terminal tail, and that Rab8 does not effectively associate with this mGluR1 variant. Therefore, the association between Rab8 and mGluRla appears to be crucial for the ability of Rab8 to regulate mGluRla signaling. We 
also show that mGluR1a displays no difference in Rab8-mediated IP signal attenuation when coexpressed with Rab8 nucleotide binding mutants, indicating that Rab8 nucleotide-binding status does not play a role in regulating mGluRla signaling.

Rab8-mediated attenuation of mGluRla signaling is reversed by PKC inhibition, suggesting that Rab8 modulates PKCdependent desensitization of mGluRla. Similar to the decrease in IP formation found in HEK 293 cells following Rab8 overexpression, we also find that GFP-Rab8 overexpression in primary mouse hippocampal neurons significantly reduces intracellular $\mathrm{Ca}^{2+}$ release in response to the activation of endogenously expressed Group I mGluRs with DHPG. This role for PKC in Rab8mediated attenuation of mGluR1a signaling is likely dependent upon PKC-dependent mGluRla phosphorylation (Hermans and Challiss, 2001).

Dominant-negative or depletion of Rab8 by siRNA significantly attenuates ERK $1 / 2$ activation by the $\alpha_{2 \mathrm{~B}} \mathrm{AR}$, but not the $\beta_{2} \mathrm{AR}$, and inhibits plasma membrane delivery of $\alpha_{2 \mathrm{~B}} \mathrm{AR}$ from the TGN (Dong et al., 2010). We find here that, although Rab8 overexpression blocks second messenger formation in response to mGluRla, agonist-stimulated ERK1/2 phosphorylation is unaltered in the presence of the GTPase. However, we did find basal ERK1/2 phosphorylation in mGluR1a-expressing cells was significantly attenuated in cells coexpressing Rab8. Thus, Rab8 may selectively contribute to the regulation of agonist-stimulated G-protein signaling, as opposed to regulating G-proteinindependent signaling mediated by the association of other proteins with mGluR1a such as Pyk2 (Nicodemo et al., 2010).

Rab8 has been implicated in numerous neuronal developmental processes such as axonal growth and dendrite arborization. Transgenic expression of dominant-negative Rab8 in Xenopus photoreceptor cells leads to rapid retinal degeneration, while depletion of Rab8 by siRNA in hippocampal neurons blocks morphological maturation through disruption of anterograde membrane traffic and impaired neurite outgrowth (Huber et al., 1995; Moritz et al., 2001). The Rab8 GEF, Rabin8, also plays a role in spine morphology as a phosphorylation-deficient Rabin8 mutant displays reduced spine head diameter (Ultanir et al., 2012). Interestingly, Rab8 has been implicated to play an important role in the delivery of proteins to primary cilia (Nachury et al., 2007). However, it is unknown whether mGluR1 is expressed in primary cilia. Additionally, multiple Rab8-associated proteins play essential roles in disease progression and pathology including glaucoma and Huntington's disease. Glaucoma is characterized by vision deficits due to the progressive loss of retinal ganglion cells and axonal degeneration of the optic nerve. Significantly higher frequencies of human glaucoma patients display mutations in the OPTN protein and the E50K mutant of OPTN has been associated with more aggressive disease phenotypes (Leung et al., 2003; Aung et al., 2005). Mice expressing this mutant form of OPTN, which no longer associates with Rab8, develop gross histological abnormalities including massive retinal apoptosis, loss of retinal ganglion cells and connecting synapses in the retina, resulting in dramatic thinning of the retina (Chi et al., 2010). Similarly, disruption of the Rab8-OPTN complex is associated with the neurodegenerative disorder, Huntington's disease. Huntington's disease is characterized by a polyglutamine expansion in the huntingtin protein leading to the death of cortical and striatal neurons. Htt directly associates with OPTN and in complex with Rab8 directs trafficking of proteins between the trans-Golgi network and plasma membrane and contributes to alterations in cell morphology. However, mutant htt protein no longer associates with OPTN and Rab8 leading to a general deficit in post-Golgi trafficking (Hattula and Peränen, 2000; del Toro et al., 2009).

In summary, our results establish a novel role for Rab8 in the regulation of mGluR1a endocytosis and signaling. In contrast to what has previously been shown for other GPCRs and Rabs, this is the first report of a Rab GTPase inhibiting GPCR endocytosis, while simultaneously attenuating receptor signaling. This opens a new and exciting avenue of research to improve our understanding of the molecular and physiological consequences of Rab GTPase-mediated regulation of GPCR signaling.

\section{References}

Anborgh PH, Seachrist JL, Dale LB, Ferguson SS (2000) Receptor/betaarrestin complex formation and the differential trafficking and resensitization of beta2-adrenergic and angiotensin II type 1A receptors. Mol Endocrinol 14:2040-2053. CrossRef Medline

Anborgh PH, Godin C, Pampillo M, Dhami GK, Dale LB, Cregan SP, Truant R, Ferguson SS (2005) Inhibition of metabotropic glutamate receptor signalling by the huntingtin-binding protein optineurin. J Biol Chem 280:34840-34848. CrossRef Medline

Aung T, Rezaie T, Okada K, Viswanathan AC, Child AH, Brice G, Bhattacharya SS, Lehmann OJ, Sarfarazi M, Hitchings RA (2005) Clinical features and course of patients with glaucoma with the E50K mutation in the optineurin gene. Invest Ophthalmol Vis Sci 46:2816-2822. CrossRef Medline

Bhattacharya M, Babwah AV, Godin C, Anborgh PH, Dale LB, Poulter MO, Ferguson SS (2004) Ral and phospholipase D2-dependent pathway for constitutive metabotropic glutamate receptor endocytosis. J Neurosci 24: 8752-8761. CrossRef Medline

Brown TC, Correia SS, Petrok CN, Esteban JA (2007) Functional compartmentalization of endosomal trafficking for the synaptic delivery of AMPA receptors during long-term potentiation. J Neurosci 27:13311-13315. CrossRef Medline

Chi ZL, Akahori M, Obazawa M, Minami M, Noda T, Nakaya N, Tomarev S, Kawase K, Yamamoto T, Noda S, Sasaoka M, Shimazaki A, Takada Y, Iwata T (2010) Overexpression of optineurin E50K disrupts Rab8 interaction and leads to a progressive retinal degeneration in mice. Hum Mol Genet 19:2606-2615. CrossRef Medline

Conn PJ, Pin JP (1997) Pharmacology and functions of metabotropic glutamate receptors. Annu Rev Pharmacol Toxicol 37:205-237. CrossRef Medline

Dale LB, Babwah AV, Ferguson SS (2002) Mechanisms of metabotropic glutamate receptor desensitization: role in the patterning of effector enzyme activation. Neurochem Int 41:319-326. CrossRef Medline

Dale LB, Seachrist JL, Babwah AV, Ferguson SS (2004) Regulation of angiotensin II type 1A receptor intracellular retention, degradation, and recycling by Rab5, Rab7, and Rab11 GTPases. J Biol Chem 279:13110-13118. Medline

del Toro D, Alberch J, Lázaro-Diéguez F, Martín-Ibáñez R, Xifró X, Egea G, Canals JM (2009) Mutant huntingtin impairs post-Golgi trafficking to lysosomes by delocalizing optineurin/Rab8 complex from the Golgi apparatus. Mol Biol Cell 20:1478-1492. CrossRef Medline

Deretic D (1997) Rab proteins and post-Golgi trafficking of rhodopsin in photoreceptor cells. Electrophoresis 18:2537-2541. CrossRef Medline

Desai MA, Burnett JP, Mayne NG, Schoepp DD (1996) Pharmacological characterization of desensitization in a human mGlul alpha-expressing non-neuronal cell line co-transfected with a glutamate transporter. $\mathrm{Br} \mathrm{J}$ Pharmacol 118:1558-2564. CrossRef Medline

Dhami GK, Ferguson SS (2006) Regulation of metabotropic glutamate receptor signaling, desensitization and endocytosis. Pharmacol Ther 111: 260-271. CrossRef Medline

Dhami GK, Anborgh PH, Dale LB, Sterne-Marr R, Ferguson SS (2002) Phosphorylation-independent regulation of metabotropic glutamate receptor signalling by G protein-coupled receptor kinase 2. J Biol Chem 277:25266-25272. CrossRef Medline

Dhami GK, Dale LB, Anborgh PH, O'Connor-Halligan KE, Sterne-Marr R, Ferguson SS (2004) G protein-coupled receptor kinase 2 regulator of G protein signaling homology domain binds to both metabotropic glutamate receptor 1a and Galphaq to attenuate signaling. J Biol Chem 279: 16614-16620. CrossRef Medline

Dhami GK, Babwah AV, Sterne-Marr R, Ferguson SS (2005) 
Phosphorylation-independent regulation of metabotropic glutamate receptor 1 signaling requires g protein-coupled receptor kinase 2 binding to the second intracellular loop. J Biol Chem 280:24420-24427. CrossRef Medline

Dingledine R, Borges K, Bowie D, Traynelis SF (1999) The glutamate receptor ion channels. Pharmacol Rev 51:7-61. Medline

Dong C, Yang L, Zhang X, Gu H, Lam ML, Claycomb WC, Xia H, Wu G (2010) Rab8 interacts with distinct motifs in alpha2B- and beta2adrenergic receptors and differentially modulates their transport. J Biol Chem 285:20369-20380. CrossRef Medline

Esseltine JL, Dale LB, Ferguson SS (2011) Rab GTPases bind at a common site within the angiotensin II type I receptor carboxyl-terminal tail: evidence that Rab4 regulates receptor phosphorylation, desensitization, and resensitization. Mol Pharmacol 79:175-184. CrossRef Medline

Evans TM, Ferguson C, Wainwright BJ, Parton RG, Wicking C (2003) Rab23, a negative regulator of hedgehog signaling, localizes to the plasma membrane and the endocytic pathway. Traffic 4:869-884. CrossRef Medline

Ferguson SS (2001) Evolving concepts in G protein-coupled receptor endocytosis: the role in receptor desensitization and signaling. Pharmacol Rev 53:1-24. Medline

Ferguson SS (2007) Phosphorylation-independent attenuation of GPCR signalling. Trends Pharmacol Sci 28:173-179. CrossRef Medline

Ferguson SS, Caron MG (2004) Green fluorescent protein tagged $\beta$-arrestin translocation as a measure of $\mathrm{G}$ protein-coupled receptor activation. Methods Mol Biol 237:121-126. Medline

Francesconi A, Duvoisin RM (2000) Opposing effects of protein kinase C and protein kinase A on metabotropic glutamate receptor signaling: selective desensitization of the inositol trisphosphate/ $\mathrm{Ca}^{2+}$ pathway by phosphorylation of the receptor-G protein-coupling domain. Proc Natl Acad Sci U S A 97:6185-6190. CrossRef Medline

Gáborik Z, Hunyady L (2004) Intracellular trafficking of hormone receptors. Trends Endocrinol Metab 15:286-293. CrossRef Medline

Geppert M, Goda Y, Stevens CF, Südhof TC (1997) The small GTP-binding protein Rab3A regulates a late step in synaptic vesicle fusion. Nature 387:810-814. CrossRef Medline

Gerges NZ, Backos DS, Esteban JA (2004) Local control of AMPA receptor trafficking at the postsynaptic terminal by a small GTPase of the Rab family. J Biol Chem 279:43870-43878. CrossRef Medline

Gerges NZ, Brown TC, Correia SS, Esteban JA (2005) Analysis of Rab protein function in neurotransmitter receptor trafficking at hippocampal synapses. Methods Enzymol 403:153-166. CrossRef Medline

Hamelin E, Thériault C, Laroche G, Parent JL (2005) The intracellular trafficking of the $\mathrm{G}$ protein-coupled receptor TPbeta depends on a direct interaction with Rab11. J Biol Chem 280:36195-36205. CrossRef Medline

Hattula K, Peränen J (2000) FIP-2, a coiled-coil protein, links Huntingtin to Rab8 and modulates cellular morphogenesis. Curr Biol 10:1603-1606. CrossRef Medline

Henry L, Sheff DR (2008) Rab8 regulates basolateral secretory, but not recycling, traffic at the recycling endosome. Mol Biol Cell 19:2059-2068. CrossRef Medline

Hermans E, Challiss RA (2001) Structural, signalling and regulatory properties of the group I metabotropic glutamate receptors: prototypic family C G-protein-coupled receptors. Biochem J 359:465-484. CrossRef Medline

Herrero I, Miras-Portugal MT, Sánchez-Prieto J (1994) Rapid desensitization of the metabotropic glutamate receptor that facilitates glutamate release in rat cerebrocortical nerve terminals. Eur J Neurosci 6:115-120. CrossRef Medline

Huber LA, Dupree P, Dotti CG (1995) A deficiency of the small GTPase rab8 inhibits membrane traffic in developing neurons. Mol Cell Biol 15:918924. Medline

Krupnick JG, Benovic JL (1998) The role of receptor kinases and arrestins in G protein-coupled receptor regulation. Annu Rev Pharmacol Toxicol 38:289-319. CrossRef Medline

Leung YF, Fan BJ, Lam DS, Lee WS, Tam PO, Chua JK, Tham CC, Lai JS, Fan DS, Pang CP (2003) Different optineurin mutation pattern in primary open-angle glaucoma. Invest Ophthalmol Vis Sci 44:3880-3884. CrossRef Medline

Lorenzen A, Samosh J, Vandewark K, Anborgh PH, Seah C, Magalhaes AC, Cregan SP, Ferguson SS, Pasternak SH (2010) Rapid and direct trans- port of cell surface APP to the lysosome defines a novel selective pathway. Mol Brain 3:11. CrossRef Medline

Moritz OL, Tam BM, Hurd LL, Peränen J, Deretic D, Papermaster DS (2001) Mutant rab8 Impairs docking and fusion of rhodopsin-bearing postGolgi membranes and causes cell death of transgenic Xenopus rods. Mol Biol Cell 12:2341-2351. Medline

Mundell SJ, Pula G, Carswell K, Roberts PJ, Kelly E (2003) Agonist-induced internalization of metabotropic glutamate receptor 1A: structural determinants for protein kinase C- and G protein-coupled receptor kinasemediated internalization. J Neurochem 84:294-304. CrossRef Medline

Mundell SJ, Pula G, McIlhinney RA, Roberts PJ, Kelly E (2004) Desensitization and internalization of metabotropic glutamate receptor la following activation of heterologous $\mathrm{Gq} / 11$-coupled receptors. Biochemistry 43: 7541-7551. CrossRef Medline

Nachury MV, Loktev AV, Zhang Q, Westlake CJ, Peränen J, Merdes A, Slusarski DC, Scheller RH, Bazan JF, Sheffield VC, Jackson PK (2007) A core complex of BBS proteins cooperates with the GTPase Rab8 to promote ciliary membrane biogenesis. Cell 129:1201-1213. CrossRef Medline

Nagabhushana A, Chalasani ML, Jain N, Radha V, Rangaraj N, Balasubramanian D, Swarup G (2010) Regulation of endocytic trafficking of transferrin receptor by optineurin and its impairment by a glaucomaassociated mutant. BMC Cell Biol 11:4. CrossRef Medline

Nakanishi S (1994) Metabotropic glutamate receptors: synaptic transmission, modulation, and plasticity. Neuron 13:1031-1037. CrossRef Medline

Ng EL, Tang BL (2008) Rab GTPases and their roles in brain neurons and glia. Brain Res Rev 58:236-246. CrossRef Medline

Nicodemo AA, Pampillo M, Ferreira LT, Dale LB, Cregan T, Ribeiro FM, Ferguson SS (2010) Pyk2 uncouples metabotropic glutamate receptor G protein signaling but facilitates ERK1/2 activation. Mol Brain 3:4. CrossRef Medline

Niswender CM, Conn PJ (2010) Metabotropic glutamate receptors: physiology, pharmacology, and disease. Annu Rev Pharmacol Toxicol 50:295322. CrossRef Medline

Olney JW (1994) Excitatory transmitter neurotoxicity. Neurobiol Aging 15: 259-260. CrossRef Medline

Parent A, Hamelin E, Germain P, Parent JL (2009) Rab11 regulates the recycling of the beta2-adrenergic receptor through a direct interaction. Biochem J 418:163-172. CrossRef Medline

Park B, Ying H, Shen X, Park JS, Qiu Y, Shyam R, Yue BY (2010) Impairment of protein trafficking upon overexpression and mutation of optineurin. PLoS One 5:e11547. CrossRef Medline

Pin JP, Duvoisin R (1995) The metabotropic glutamate receptors: structure and functions. Neuropharmacology 34:1-26. CrossRef Medline

Pin JP, Joly C, Heinemann SF, Bockaert J (1994) Domains involved in the specificity of $\mathrm{G}$ protein activation in phospholipase C-coupled metabotropic glutamate receptors. EMBO J 13:342-348. Medline

Pin JP, Galvez T, Prézeau L (2003) Evolution, structure, and activation mechanism of family $3 / \mathrm{C}$ G-protein-coupled receptors. Pharmacol Ther 98:325-354. CrossRef Medline

Reid HM, Mulvaney EP, Turner EC, Kinsella BT (2010) Interaction of the human prostacyclin receptor with Rab11: characterization of a novel Rab11 binding domain within alpha-helix 8 that is regulated by palmitoylation. J Biol Chem 285:18709-18726. CrossRef Medline

Ribeiro FM, Pires RG, Ferguson SS (2011) Huntington's disease and Group I metabotropic glutamate receptors. Mol Neurobiol 43:1-11. CrossRef Medline

Schoepp DD, Johnson BG (1988) Selective inhibition of excitatory amino acid-stimulated phosphoinositide hydrolysis in the rat hippocampus by activation of protein kinase C. Biochem Pharmacol 37:4299-4305. CrossRef Medline

Seachrist JL, Ferguson SS (2003) Regulation of G protein-coupled receptor endocytosis and trafficking by Rab GTPases. Life Sci 74:225-235. CrossRef Medline

Seachrist JL, Anborgh PH, Ferguson SS (2000) beta 2-adrenergic receptor internalization, endosomal sorting, and plasma membrane recycling are regulated by rab GTPases. J Biol Chem 275:27221-27228. Medline

Seachrist JL, Laporte SA, Dale LB, Babwah AV, Caron MG, Anborgh PH, Ferguson SS (2002) Rab5 association with the angiotensin II type 1A receptor promotes Rab5 GTP binding and vesicular fusion. J Biol Chem 277:679-685. Medline

Ultanir SK, Hertz NT, Li G, Ge WP, Burlingame AL, Pleasure SJ, Shokat KM, Jan 
LY, Jan YN (2012) Chemical genetic identification of NDR1/2 kinase substrates AAK1 and Rabin8 uncovers their roles in dendrite arborization and spine development. Neuron 73:1127-1142. CrossRef Medline

van Ijzendoorn SC, Mostov KE, Hoekstra D (2003) Role of rab proteins in epithelial membrane traffic. Int Rev Cytol 232:59-88. CrossRef Medline
Xie C, Markesbery WR, Lovell MA (2000) Survival of hippocampal and cortical neurons in a mixture of MEM+ and B27-supplemented Neurobasal medium. Free Radic Biol Med 28:665-672. CrossRef Medline

Zerial M, McBride H (2001) Rab proteins as membrane organizers. Nat Rev Mol Cell Biol 2:107-117. CrossRef Medline 